Performance - Vol.22 No.2 September 2016

\title{
PERANAN AKUNTANSI TERHADAP MANAJEMEN KEUANGAN USAHA KECIL MENENGAH (UKM) DAN KOPERASI DI INDONESIA
}

Oleh,

Dr. Riswan, MM, Ak

Dosen Fakultas Ekonomi dan Bisnis

Universitas Jenderal Soedirman

\section{ABSTRACT}

This article discusses the importance of accounting for SMEs and cooperatives, accounting Role Of Financial Management of SMEs and cooperatives in Indonesia and Accountability accounting for SMEs and Cooperatives in Indonesia.

Keywords: Importance of Accounting, The Role of Accounting, Financial Management Responsibility Accounting, SMEs and cooperatives.

\section{ABSTRAKSI}

Artikel ini membahas pentingnya akuntansi dalam usaha kecil menengah dan koperasi, peranan akuntansi terhadap manajemen keuangan usaha kecil menengah dan koperasi di Indonesia dan akuntansi pertanggungjawaban usaha kecil menengah dan koperasi di Indonesia

Kata Kunci : Pentingya Akuntansi, Peranan Akuntansi, Manajemen Keuangan Akuntansi Pertanggungjawaban, UKM, dan Koperasi.

\section{PENDAHULUAN}

UKM sukses adalah kelompok UKM yang mampu memanfaatkan sumber daya yang tersedia terutama yang bernilai ekonomi rendah termasuk limbah menjadi barang-barang yang bernilai ekonomi tinggi. Berbagai produk UKM sukses telah membuktikan bahwa kelompok UKM ini telah mampu melakukan kegiatan usaha yang memiliki nilai tambah cukup besar seperti pengrajin bonggol kayu yang menghasilkan meja dan kursi dengan nilai tambah mencapai lebih dari $600 \%$, atau pengrajin eceng gondok yang bukan saja mampu menjual produknya dengan harga yang mencapai lebih dari 500\% dibandingkan dengan harga bahan baku yang digunakannya 
tetapi juga telah mengurangi pencemaran lingkungan sehingga dapat mengurangi externality economics yang sebelumnya harus di tanggung oleh masyarakat. Keberhasilan UKM ternyata tidak hanya karena keahlian yang dimiliki, tetapi juga dipengaruhi oleh banyak faktor antara lain

a) Jiwa kewirausahaan dan krea-tivitas individual yang melahirkan inovasi.

b) Ketersediaan bahan baku, iklim usaha, dukungan financial, ketersediaan informasi baik pengetahuan dan teknologi, ketersediaan pasar dan dukungan infrastruktur.

Penumbuhan usaha yang diinspirasikan dari adanya kreativitas dan inovasi merupakan model ideal dalam kerangka pembangunan yang bertujuan mengoptimalkan potensi sumberdaya tersediya dan bersifat partisipatif. Oleh sebab itu, peng-ungkapan kita-kiat usaha dan penu-laran usaha tersebut sangat diperlukan untuk mengurangi pengangguran dan meningkatkan pendapatan masyarakat.

Profil UKM sukses adalah gambaran morphologis dari UKM yang bersangkutan dilihat dari aspek usaha dan sifat kewirausahaan dari pengusaha UKM tersebut. Hal tersebut terlihat dari antara lain kemam-puannya dalam menciptakan nilai tambah dari produk-produk yang diha-silkan serta kemampuannya memanfaatkan potensi sumberdaya lokal dan sumber daya alam. Dengan memperhatikan profil UKM sukses dan ketersediaan sumberdaya lokal sedemikian besar, serta masalah pengangguran dan kemiskinan yang belum dapat terpecahkan, maka pengembangan UKM sukses merupakan salah satu solusi yang perlu dikaji dalam rangka pemberdayaan kelompok miskin terutama di pedesaan. Pembukaan usaha baru dengan memanfaatkan inovasi yang telah dibangun oleh kelompok UKM sukses perlu dikem-bangkan dengan berbagai cara seperti melakukan replikasi, kerja sama kemitraan dan bentuk-bentuk lainnya. Sebagai langkah awal dari usaha pengembangan ini diperlukan adanya suatu kajian yang komperhensif untuk dapat menginventarisirs, mengidentifikasi, merumuskan berbagai faktor yang mempengaruhi keberhasilan kelompok UKM untuk dijadikan bahan masukan dalam rangka penyusunan model pernumbuhan usaha baru yang berbasis kreatifitas dan inovasi kelompok UKM sendiri serta mela-kukan pemasaran yang baik, bertujuan untuk menciptakan sukses dalam usaha kecil menengah ini.

http://consumerbehaviour.lecture.ub.a c.id/2011/12/artikel-tentang-ukm/

\section{PENTINGNYA AKUNTANSI}

Akuntansi berasal dari kata dalam bahasa Inggris, yaitu accounting, yang berarti menghitung atau mempertanggungjawabkan. Hampir seluruh kegiatan bisnis di seluruh dunia menggunakan kata ini untuk mengambil keputusan sehingga akuntansi sering kali disebut sebagai kata bisnis. 


\section{Performance - Vol.22 No.2 September 2016}

Akuntansi adalah proses mencatat, mengklasifikasi, meringkas, megolah dan menyajikan data, transaksi serta kejadian yang berhubungan dengan keuangan sehingga dapat digunakan oleh orang yang mengguna-kannya untuk pengambilan suatu ke-putusan serta tujuan lainnya. Adapun fungsi utama akuntansi adalah sebagai informasi keuangan suatu organisasi. (Siegal, et al, 1995).

Pada dasarnya proses akuntansi adalah membuat output laporan rugi laba, laporan perubahan modal, dan laporan neraca sutau perusahaan atau organisasi lainnya. Oleh karena itu setiap laporan harus mencantumkan nama perusahaan, nama laporan, dan tanggal penyusunan atau jangka waktu laporan tersebut untuk memudahkan orang dalam memahaminya. Laporan dapat bersifat periodik, bisa juga bersifat suatu waktu tertentu saja.

Akuntansi memiliki proses yang terdiri dari tahapan-tahapan untuk dapat menghasilkan laporan yang diinginkan dan dilakukan oleh akuntan. (Meighs \& Meighs, 1990).

\subsection{Mengklarifikasi Transaksi}

Tahap awal dalam akuntansi adalah melakukan pembagian transaksi suatu organisasi atau perusahaan ke dalam jenis-jenis tertentu yang telah ditetapkan sebelumnya, misalnya membagi transaksi yang masuk ke dalam penjualan, pembelian, pengeluaran kas, penerimaan kas, dan sebagainya ke dalam masingmasing bagian. Sedangkan untuk transaksi yang jumlahnya kecil dan jarang terjadi bisa sama-sama dimasukkan ke dalam jenis kategori yang sama, yaitu transaksi rupa-rupa.

\subsection{Mencatat dan Merangkum}

Proses akuntansi selanjut-nya adalah melakukan pencatatan. Masukkanlah transaksi yang ada kedalam jurnal yang tepat sesuai urutan transaksi terjadi atau kejadiannya. Sumber-sumber yang dapat dijadikan bukti adanya transaksi antara lain kertas-kertas bisnis semacam bon, bill, nota, struk, sertifikat, dan sebagainya.

Jurnal yang umumnya ada pada jurnal akuntansi adalah jurnal penjualan, jurnal pembelian, jurnal penerimaan kas, jurnal penge-luaran kas, dan jurnal umum. Proses selanjutnya adalah mema-sukkan jurnal ke dalam buku besar secara berkala. Hasil pemindahan ke dalam buku besar tersebut akan terlihat dari rangkuman neraca percobaan.

\subsection{Menginterpretasikan dan Melaporkan}

Proses akuntansi yang terakhir adalah melakukan pembuatan kesimpulan dari kegiatan atau pekerjaan laporan keuangan sebelumnya. Segala hal yang berhubungan dengan keuangan perusahaan dituangkan dalam laporan keuangan tersebut. Dari informasi laporan keuangan (laporan rugi laba, laporan modal, dan neraca), seseorang dapat mengetahui apa yang terjadi pada perusahaan, 
apakah sudah sesuai dengan tujuan perusahaan. Informasi tersebut dapat menjadi acuan atau pedoman bagi manajemen untuk mengambil keputusan kebijakan pada organisasi perusahaan demi mencapai kondisi yang diinginkan.

\section{PERANAN AKUNTANSI TER- HADAP MANAJEMEN KEU- ANGAN DI UMKM}

Penulis meyakini ini bahwa permasalahan tentang pengolahan dana merupakan faktor kunci yang dapat menyebabkan keberhasilan, atau justru kegagalan, UMKM. Meskipun banyak faktor lain yang mempengaruhi UMKM tetapi persoalanpersoalan di UMKM lazimnya muncul akibat kegagalan UMKM mengelola dana. Kesalahan dalam pengolahan dana berupa kas dapat menyebabkan UMKM secara mendadak mengalami kekurangan uang tunai untuk menjalankan operasional harian. Kekurangcermatan pengolahan dana menyebabkan wirausahawan mencampur adukkan dana perusahaan dengan dana pribadi. Selanjutnya, pengolahan dana yang buruk berakibat perusahaan tidak dapat mencegah, mendeteksi maupun mengoreksi tindak kecurangan yang terjadi di perusahaan. Oleh karena itu, adalah hal yang dapat dimaklumi jika bank-bank pemberi kredit selalu mensyaratkan UMKM calon penerima kredit untuk menyampaikan informasi keuangan. Berdasar informasi keuang- an tersebut bank menginterpretasikan kemampuan UMKM dalam mengelola dana, dan memprediksi resiko kegagalan usaha yang dijalankan karena ketidakmampuan UMKM dalam mengelola dana. (Sony Warsono, et.al, 2010)

Metode praktis dan manjur dalam pengelolaan dana di perusahaan bisnis, termasuk UMKM, adalah dengan mempraktikan akuntansi secara baik. Pada prinsipnya, akuntansi adalah sebuah sistem yang mengolah transaksi menjadi informasi keuangan. Dengan demikian, akuntansi menjadikan UMKM dapat memperoleh berbagai informasi keuangan yang penting dalam menjalankan bisnisnya. Berikut ini beberapa informasi keuangan yang dapat diperoleh UMKM jika mempraktikan akuntansi dengan baik dan benar : (IAI, 2007)

\subsection{Informasi kinerja perusahaan ;}

Akuntansi menghasilkan laporan laba/rugi (income statements) yang mencerminkan kemampuan UMKM dalam menggunakan laporan laba/rugi sebagai bahan evaluasi secara periodik. Jika laporan laba/rugi menunjukkan bahwa perusahaan mengalami rugi atau penurunan laba disbanding periode sebelumnya maka perusahaan menganalisis penyebab-penyebab terjadinya kerugian atau penurunan laba. Sebailknya, jika laporan laba/rugi 
menunjukkan bahwa UMKM memperoleh laba atau kenaikan laba disbanding periode sebelumnya maka perusahaan dapat mempertahankan proses bisnis yang telah dilakukan, atau mengembangkan proses bisnis agar laba meningkat. Horngren, et.al, 1999).

\subsection{Informasi penghitungan pajak;}

Berdasar laporan laba/rugi yang dihasilkan akuntansi, UMKM dapat secara akurat menghitung jumlah pajak yang harus dibayar untuk periode tertentu, atau bahkan dapat mengajukan restitusi pajak. (Anthony Robert, et.al, 1995).

\subsection{Informasi posisi dana peru- sahaan;}

Akuntansi menghasilkan
neraca (balance sheets) yang
mencerminkan penggunaan dana
berupa aset (disebut harta atau
aktiva) dan sumber-sumber peme-
rolehan dana yang berasal dari
utang dan ekuitas. Informasi ini
penting karena memberi gambaran
tentang posisi keuangan peru-
sahaan pada tanggal tertentu.
Berdasar informasi keuangan yang
terdapat di neraca, perusahaan
maupun pihak lain dapat men-
getahui apakah aset yang dimiliki
oleh perusahaan pendanaannya
sebagaian besar berasal dari utang
atau ekuitas. Perusahaan dengan

komposisi utang yang sangat besar beresiko tinggi karena perusahaan harus menanggung biaya tetap berupa bunga utang.

\subsection{Informasi perubahan modal pe- milik;}

Akuntansi menghasilkan laporan perubahan ekuitas (statements of equity changes) yang mencerminkan perubahan sumber pendanaan, terutama yang berasal dari ekuitas. Pemilik perusahaan membutuhkan informasi ini untuk mengetahui perkembangan modal yang telah ditanamkan ke perusahaan. Pemerolehan laba yang tinggi tidak selalu mencerminkan kesuksesan perusahaan jika ternyata pengambilan dana oleh pemilik melebihi laba yang dihasilkan.

\subsection{Informasi pemasukan dana pe- ngeluaran kas;}

Akuntansi menghasilkan laporan arus kas (statements of cash flow) yang mencerminkan pemerolehan dan penggunaan aset utama berupa kas. Pengolahan dana perusahaan lazimnya berhubungan positif dengan keberhasilan perusahaan; semakin baik pengolahan kas maka semakin besar kesuksesan yang diraih perusahaan, dan sebaliknya. 
2.6 Informasi perencanaan kegiatan;

Akuntasni menghasilkan laporan anggaran (budget) yang menggambarkan kegiatan-kegiatan yang direncanakan perusahaan selama periode tertentu, beserta pendanaan yang akan dibutuhkan atau yang diperoleh.

\subsection{Informasi besar biaya;}

Akuntansi menghasilkan informasi tentang beraneka ragam biaya yang telah dikeluarkan beserta informasi lainnya yang terkait dengan pengeluaran biaya tersebut. Sebagai contoh, akuntansi dapat menyediakan informasi tentang fluktuasi biaya yang harus ditanggung perusahaan per hari, minggu, bulan, dst. (Sony Warsono, et.al, 2010, Horngren, et.al, 1995).

\section{AKUNTANSI PERTANGGUNG- JAWABAN}

\subsection{Akuntansi Pertanggungjawa-}

ban (responsibility accounting) adalah sistem akuntansi yang mengakui berbagai pusat pertanggungjawaban pada keseluruhan organisasi dan mencerminkan rencana serta tindakan setiap pusat pertanggungjawaban dengan menetapkan penghasilan dan biaya tertentu bagi pusat yang memiliki tanggung jawab bersangkutan. Untuk membangun sistem akuntansi pertanggungjawaban yang baik diperlukan sejumlah persyaratan yang saling terkait satu dengan lainnya.

Beberapa persyaratan untuk membentuk dan mempertahankan sistem akuntansi pertanggungjawaban adalah :

a. Alokasi dan Pengelompokkan Tanggung Jawab

Sistem akuntansi pertanggungjawaban harus didasarkan pada alokasi dan pengelompokan tanggung jawab manajerial ke berbagai unit serta tingkatan dalam organisasi koperasi dengan tujuan membentuk anggaran bagi masing-masing unit kerja tersebut.

\section{b. Sesuai Bagan Organisasi}

Sistem akuntansi pertanggungjawaban harus disesuaikan dengan struktur organisasi koperasi di mana ruang lingkupnya telah ditentukan. Wewenang akan mendasari pertanggungjawaban atas biaya tertentu.

\section{c. Anggaran yang jelas}

Anggaran yang disusun harus menunjukkan secara jelas biaya yang dikendalikan oleh personel unit kerja bersangkutan. Jadi, setiap personel unit kerja yang diberi wewenang mengelola unit kerjanya mengetahui dengan 
jelas tingkat tanggung jawab yang diembannya. (Rudianto, 2010).

\subsection{Jenis Pusat Pertanggung- jawaban}

Dari berbagai fungsi dan tingkatan manajemen yang dimiliki suatu koperasi secara keseluruhan dapat dikelompokan ke dalam tiga pusat pertanggungjawaban. Keseluruhan fungsi dan tingkatan manajemen, seperti yang tercantum dalam struktur organisasi berbagai koperasi, dapat dibagi menjadi beberapa jenis, yaitu :

\section{a. Pusat Biaya}

Pusat biaya (cost center) adalah bagian terkecil dari kegiatan atau bidang tanggung jawab dimana biayanya akan diakumulasikan. Biasanya pusat biaya berbentuk departemen tersendiri, walaupun tidak menutup kemungkinan suatu pusat departemen terdiri dari beberapa pusat biaya. Sebagai contoh, koperasi susu kemasan memiliki unit penelitian dan pengembangan. Jika unit semacam ini tidak diberikan wewenang untuk menjual hasil penelitian dan pengembangan yang dilakukannya, unit ini hanya akan mengeluarkan biaya untuk berbagai keper- luan penelitian dan pengembangan yang dilakukannya. Unit kerja semacam inilah yang disebut pusat biaya.

\section{b. Pusat Laba}

Pusat laba (profit center) adalah suatu bagian (unit kerja) dari suatu koperasi yang sering kali disebut sebagai divisi yang bertanggung jawab atas pendapatan maupun pengeluaran koperasi. Sebagai contoh, jika salah satu koperasi produsen susu kemasan yang berlokasi di Jawa Barat memiliki kantor pemasaran di Jakarta, divisi pemasaran itu merupakan pusat laba bagi koperasi produsen susu kemasan tersebut. Selain bertanggung jawab terhadap pendapatan dari aktivitas pemasaran yang dilakukannya pada wilayah tertentu, divisi tersebut juga bertanggung jawab atas biaya-biaya yang dikeluarkan oleh divisinya.

\section{c. Pusat Investasi}

Pusat investasi (investment center) adalah satu bagian dari organisasi yang bertanggung jawab atas pendapatan dan biaya terkait dengan modal yang digunakan oleh bagian tersebut. Dalam prakteknya, istilah pusat 
investasi jarang digunakan oleh berbagai koperasi yang ada. (Rudianto, 2010, Edmns, Thomas P, et.al).

\subsection{Perilaku Manusia}

Akuntansi pertanggungjawaban menekankan suatu pelajaran penting kepada para manajer maupun para pengurus koperasi, yaitu perilaku para pengelola koperasi sering kali sangat dipengaruhi oleh bagaimana kinerjanya (performance) diukur. Jika para manajer unit kerja mengetahui dengan jelas ukuran yang digunakan oleh koperasi dalam menilai kinerja unit kerja yang dipimpinnya, mereka akan berusaha keras untuk mencapai target yang telah ditetapkan oleh koperasi. Untuk mencapai target-target itu, diperlukan sejumlah faktor pendukung yang saling terkait satu dengan yang lainnya.

Faktor-faktor yang terkait dengan perilaku manusia yang sangat mendukung tercapainya target-target yang ditetapkan oleh koperasi atas unit kerja antara lain :

\section{a. Keteladanan}

Contoh dan keteladanan dari setiap manajer unit kerja dalam mentaati tanggung jawab atas biaya dan laba yang mereka gariskan akan sangat berpengaruh terhadap seluruh anggota unit kerja tersebut.

\section{b. Motivasi}

Motivasi yang dimiliki oleh seluruh anggota unit kerja untuk mencapai target-target yang telah ditetapkan akan menjadi pendorong utama dalam mencapai keberhasilan departemen.

\section{c. Komunikasi}

Komunikasi yang intensif dan efektif antar anggota organisasi, antara staf dan penyila, antara penyila dan manajer, serta antar divisi (unit kerja) juga akan sangat berpengaruh terhadap kemampuan organisasi dalam mencapai targettarget yang ditetapkan. (Rudianto., 2010).

\subsection{Pelaporan}

Akuntansi pertanggungjawan merupakan suatu program yang melibatkan semua tingkatan manajemen operasi, dibantu Oleh bagian akuntansi dan bendahara koperasi yang menyediakan laporan secara harian, mingguan, atau bulanan. Proses penyusunan laporan pertanggungjawaban mencakup penyusunan laporan untuk berbagai tingkat manajemen.

Laporan akuntansi pertanggungjawaban kepada berbagai 
tingkat manajemen dalam suatu koperasi dapat dibagi menjadi :

1. Laporan pelaksanaan tanggung jawab, yaitu laporan yang merupakan laporan tanggung jawab (accounttability) yang memiliki dua tujuan, yaitu :

a. Memberikan informasi kepada Manajer, Pengurus, dan Pengawas mengenai pelaksanaan atau kinerja dalam bidangbidang yang menjadi tanggung jawabnya.

b. Mendorong para manajer dan atasan untuk mengambil tindakan langsung yang diperlukan guna memperbaiki kinerja.

2. Laporan informasi, yaitu laporan yang disusun dengan tujuan agar para manajer memperoleh informasi yang relevan dengan bidangnya, walaupun tidak perlu berkaitan langsung dengan tanggung jawab khusus atas kinerjanya. Laporan informasi mencakup bidang sasaran yang berbeda dan lebih luas ketimbang laporan kinerja.

Dalam jangka pendek, laporan pelaksanaan tanggung jawab dianggap lebih penting dibandingkan laporan informasi keuangan karena adanya kebutuhan langsung dan mendesak agar perusahaan berjalan sebagaimana mestinya. Tetapi dalam jangka panjang, laporan informasi yang berkaitan dengan kemajuan dan pertumbuhan usaha koperasi juga sangat penting (Rudianto 2010, IAI 2007).

\subsection{Kriteria laporan yang baik}

Untuk membuat laporan berkualitas baik, ada beberapa kriteria yang harus dipenuhi, yaitu :

1. Ditujukan pada pihak yang tepat

Laporan harus sesuai dengan organisasi, yaitu harus ditujukan kepada personel yang bertanggung jawab mengendalikan bidang yang dilaporkan.

2. Konsisten

Bentuk dan isi laporan harus konsisten setiap kali diterbitkan. Jadi, perubahan hanya harus dilakukan jika sangat diperlukan dan dengan alas an yang tepat.

3. Tepat waktu

Laporan harus disusun dan disampaikan sesuai dengan waktu diperlukannya laporan tersebut.

4. Teratur 
Laporan harus disampaikan secara berkala dan teratur dari waktu ke waktu.

\section{Mudah dipahami}

Laporan harus mudah dicerna dan dipahami oleh pihak pembacanya. Karena itu, harus dihindari penggunaan istilah-istilah akuntansi yang sulit dan tidak dipahami oleh pihak pembacanya yang mungkin tidak memiliki latar belakang akuntansi. Namun, jika penggunaan istilah akuntansi tertentu tidak terhindarkan, harus diberikan keterangan tambahan secukupnya.

6. Penjelasan yang terinci

Laporan harus memberikan penjelasan yang terinci dan memadai tetapi tidak berteletele tentang isi laporannya. Jika memang diperlukan, laporan dapat mencantumkan jumlah rupiah maupun kuantitas barang.

7. Dapat dibandingkan

Laporan harus memuat berbagai angka yang dapat dibandingkan, baik antara angka actual dan anggaran, antara satu periode dan periode sebelumnya, atau antara standard an actual.

8. Bersifat analitis
Laporan harus berupa analisis atas berbagai hal yang dilaporkan, seperti kartu jam kerja, daftar barang rusak, pesanan kerja, surat permintaan bahan, kemacetan mesin, kualitas bahan, dan sebagainya.

9. Tingkat efisiensi

Laporan harus menyampaikan tentang kemampuan atau ketidakmampuan setiap unit kerja pelapor dalam mencapai tingkat efisiensi yang diharapkan (Rudianto 2010).

\subsection{Alokasi Biaya}

Dari ketiga jenis pusat pertanggung jawaban yang telah dibahas, yaitu pusat biaya, pusat pendapatan, dan pusat investasi, ketiganya terkait erat dengan upaya pengalokasian tanggung jawab tertentu. Pusat biaya terkait erat dengan upaya pengalokasian tanggung jawab untuk memperoleh pendapatan dan biaya ke suatu divisi tertentu, dan pusat investasi merupakan bagian dari upaya untuk mengalokasikan tanggung jawab untuk memperoleh pendapatan serta biaya dengan menggunakan modal tertentu.

Dari ketiga jenis pusat pertanggungjawaban tersebut, pusat biaya sering kali mendapat per- 
hatian yang lebih sering karena upaya untuk mengalokasikan biaya secara adil ke berbagai unit kerja pada suatu koperasi merupakan persoalan yang sering terjadi. Berbagai koperasi lebih sering menghadapi persoalan yang terkait dengan pusat biaya dibandingkan persoalan yang terkait dengan pusat pertanggungjawaban pendapatan dan pusat pertanggungjawaban investasi. Secara umum biaya yang dikeluarkan koperasi selama suatu periode tertentu dialokasikan dengan tujuan (Matz, et.al, 1993) :

1. Meramalkan dampak Ekonomis dari keputusan-keputusan yang dibuat para pengelola organisasi koperasi

2. Memberikan motivasi kepada para pengelola organisasi

3. Mengukur pendapatan, SHU, dan aktiva

4. Menetapkan harga

Karena itu, dalam proses pengalokasian biaya keempat faktor tersebut harus dijadikan dasar pertimbangan bagi para manajemen puncak agar alasannya menjadi lebih jelas. Setelah tujuan ditetapkan, Pengurus, Pengawas, dan Manajemen koperasi harus mempertimbangkan beberapa unsur pendukung yang dapat mempengaruhi keberhasilan pe- ngalokasian dan pengendalian biaya.

Beberapa faktor yang mempengaruhi pengendalian biaya secara bertanggung jawab adalah :

\section{Faktor Internal}

Ada sejumlah faktor internal yang berpengaruh terhadap kemampuan unit kerja dalam mengendalikan biaya yang menjadi tanggung jawabnya, yaitu :

- Produktivitas unit kerja tersebut

- Perilaku biaya

- Tenaga kerja yang digunakan

- Kekerabatan para pekerja

- dan sebagainya (Rudianto 2010)

2. Saling Ketergantungan dengan Departemen lain

Hubungan dan saling keterkaitan antara satu unit kerja dengan unit kerja lainnya akan sangat mempengaruhi kemampuan setiap unit kerja dalam mengendalikan biaya yang menjadi tanggung jawabnya. Kualitas kerja sama antara satu unit kerja dengan unit kerja lainnya dalam mengendalikan biaya unit kerja tersebut akan dipengaruhi oleh beberapa faktor, seperti : 
- Keandalan setiap unit kerja/divisi

- Kerja sama antar unit kerja/divisi

- Keluwesan setiap unit kerja/divisi( Rudianto 2010)

\section{Faktor Lingkungan}

Lingkungan Organisasi adalah segala sesuatu yang berbeda di luar organisasi dimana organisasi tersebut beroperasi. Lingkungan organisasi juga berpengaruh terhadap kemampuan setiap unit kerja dalam mengendalikan biayanya. Faktor-faktor lingkungan ini mencakup :

- Pangsa pasar/pelanggan yang dimiliki

- Tingkat inflansi

- Stabilitas politik

- Nilai tukar mata uang

- dan sebagainya

Ketiga faktor itu harus diperhatikan dan dipertimbangkan Oleh manajemen dan pengurus pada saat merancang sistem pengendalian biaya bagi koperasi. Mengabaikan ketiga hal tersebut dapat menyebabkan sistem pengendalian biaya yang disusun kurang efektif dalam mencapai sasarannya.

Berbagai jenis biaya yang sudah dikenal dalam sebuah koperasi (khususnya koperasi produsen), mulai dari biaya bahan baku langsung, biaya tenaga kerja langsung, biaya overhead, biaya pemasaran, hingga biaya administrasi dan umum, biasanya dapat dibebankan secara jelas ke suatu departemen tertentu, kecuali biaya overhead. Biaya overhead biasanya terdiri dari biaya bahan penolong, biaya tenaga kerja penolong, dan biaya pabrikasi lainnya. Biaya pabrikasi lainnya terdiri dari berbagai biaya yang mendukung proses produksi, seperti biaya listrik, biaya penyusutan aktiva tetap, biaya pemeliharaan, dan berbagai biaya lainnya. Biaya pabrikasi semacam ini tidak dapat dibebankan secara langsung ke suatu unit kerja tertentu karena yang menikmati manfaat dari biaya semacam itu sering kali tidak hanya satu unit kerja saja, tetapi beberapa unit kerja sekaligus. Jadi, pembebanan biaya pabrikasi semacam itu ke suatu unit kerja tertentu memerlukan perhitungan khusus.

Karena sebagian dari biaya overhead dapat langsung dibebankan ke suatu unit kerja tertentu secara jelas sementara sebagaian lagi tidak, koperasi sering kali 
menentukan suatu tariff overhead tertentu sebagai dasar perhitungan biaya overhead. Metode yang sering kali digunakan untuk menghitung tariff overhead adalah mendistribusikan total biaya overhead yang dikeluarkan ke berbagai kegiatan, produk, atau pekerjaan. Namun prosedur pengalokasian ini tidak dapat diterapkan pada pengendalian biaya dalam akuntansi pertanggungjawaban.

Sistem pengendalian biaya dalam akuntansi pertanggungjawaban dapat menggunakan sistem alokasi biaya overhead berdasar jam pemakaian, atau jam kerja, pada unit kerja yang menerima manfaat jasa overhead tertentu. Distribusi ini dapat dipandang sebagai pembelian oleh unit kerja yang menerima jasa dan dipandang sebagai penjualan oleh unit kerja yang memberi jasa. Distribusi kepada unit kerja penerima didasarkan pada tariff tertentu, seperti tariff penagihan, tariff jam kerja terjual, tarif pembebanan, atau tarif transfer. Metode ini didasarkan pada pemikiran bahwa unit kerja tersebut membeli jasa dengan cara yang sama seperti membeli bahan langsung dan mengangkat pekerja langsung.

Untuk menentukan tarif penagihan antar unit kerja, serangkaian langkah berikut harus digunakan :

1. Menyusun anggaran biaya untuk setiap unit kerja jasa menurut sifatnya (kepenyilaan, perlengkapan, listrik, dan lain-lain)

2. Mengelompokan biaya ke dalam biaya tetap dan biaya variable

3. Menentukan tarif dengan membagi total anggaran biaya unit kerja dengan jumlah jam pelayanan yang dibutuhkan (Rudianto 2010)

\subsection{Pengendalian Biaya}

Disamping unsur-unsur pendukung yang telah dibahas, dalam proses mendesain sistem pengalokasian dan pengendalian biaya juga perlua diperhatikan beberapa hal penting lainnya. Untuk merancang sistem pengendalian biaya yang efektif, ada beberapa kriteria yang harus dipenuhi ( Rudianto 2010), yaitu :

1. Rancangan teknis yang kokoh mencakup :

a. Penetapan sasaran yang memberikan tantangan

b. Penetapan sasaran yang realistis (bisa dicapai) 
c. Sistem pengendalian dan pelaporan biaya yang memisahkan antara biaya yang terkendali dan di luar kendali manajer

2. Gaya manajemen yang tanggap terhadap perilaku anggota organisasi. Karena itu diperlukan manajemen dengan perpaduan :

a. Keikutsertaan para manajer dalam penetapan sasaran kegiatannya sendiri

b. Kepemimpinan manajer yang eksekutif

c. Jaringan komunikasi yang terbuka

d. Pencegahan dini terhadap pelaksanaan kerja yang tidak optimal

Salah satu langkah penting dalam mendesain sistem akuntansi pertanggungjawaban adalah pembentukan garis dan bidang pertanggungjawaban yang jelas. Setiap kotak pada bagan organisasi mewakili satu segmen (pusat biaya, divisi, unit kerja, dan lainlain) yang membuat laporan dan yang menerima laporan mengenai fungsi yang menjadi tanggung jawabnya. (Matz, 1993).

Contoh akuntansi pertanggungjawaban ( Rudianto 2010) :

Koperasi "DoReMi" adalah sebuah koperasi produsen peralatan elektronik yang berlokasi di Jakarta. Koperasi ini memproduksi empat jenis produk, yaitu : DVD player, active speaker, computer, dan setrika. Koperasi ini menyusun sistem akuntansi pertanggungjawabannya berdasarkan struktur organisasi koperasi. Sebagaian dari struktur organisasi yang dimiliki koperasi ini adalah sebagai berikut :

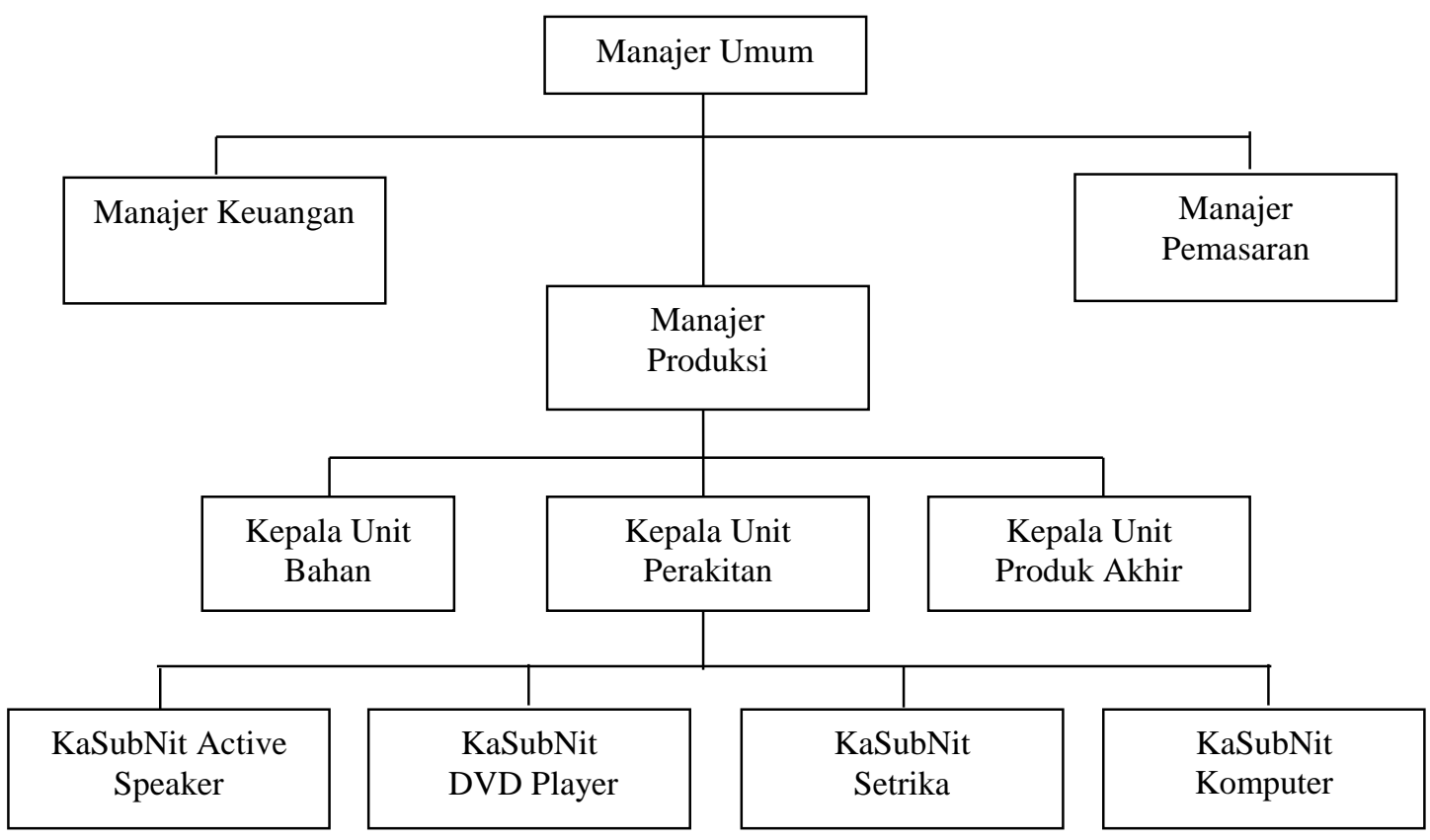




\section{Performance - Vol.22 No.2 September 2016}

Koperasi "DoReMi"

Laporan Realisasi Biaya

Biaya Overhead

Kepada Manajer Umum

Bulan : April 2010

\begin{tabular}{|c|c|c|c|}
\hline Manajer & Jumlah & Anggaran & Selisih \\
\hline Manajer Umum & 11.000 .000 & 15.000 .000 & 4.000 .000 \\
\hline Manajer Pemasaran & 93.000 .000 & 100.000 .000 & 7.000 .000 \\
\hline Manajer Produksi & 442.000 .000 & 450.000 .000 & 8.000 .000 \\
\hline Manajer Keuangan & 18.000 .000 & 20.000 .000 & 2.000 .000 \\
\hline Total & 564.000 .000 & 585.000 .000 & 21.000 .000 \\
\hline
\end{tabular}

\section{Laporan Realisasi Biaya}

Biaya Overhead

Kepada Manajer Produksi

Bulan : April 2010

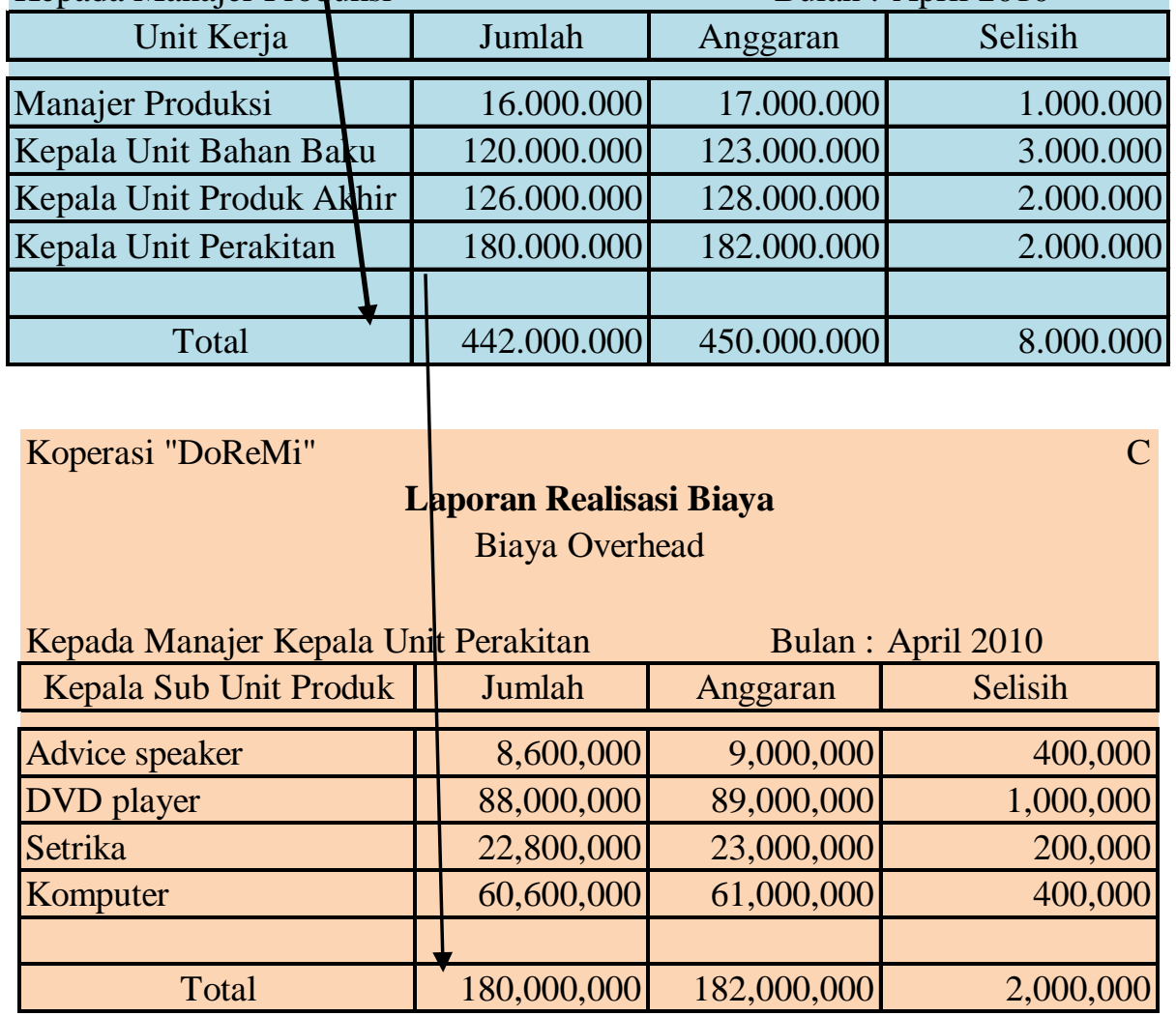




\begin{abstract}
Pelaporan yang disusun dalam sistem pertanggungjawaban ini mengikuti struktur organisasi koperasi. Empat kepala sub unit produk mempertanggungjawabkan biaya yang dikelolanya kepada Kepala Unit Perakitan. Kepala Unit Perakitan
\end{abstract} mempertanggungjawabkan dan melaporkan unit kerjanya kepada Manajer Produksi. Sedangkan Manajer produksi mempertanggungjawabkan dan melaporkan biaya yang dikelola divisinya kepada Manajer Umum koperasi. Tentu saja Manajer Umum koperasi tersebut bertanggung jawab kepada Pengurus Koperasi.

Dengan pola seperti ini, sistem pertanggungjawaban dan pelaporan biaya yang dikelola oleh masing-masing pelaksana organisasi sesuai dengan struktur organisasi yang dimiliki koperasi. Jika dibandingkan dengan anggaran yang telah disusun, sistem pengendalian biaya pada koperasi lebih mudah dilaksanakan Rudianto,2010).

\section{KESIMPULAN}

1. Akuntansi sangat penting untuk mengetahui kinerja manajemen keuangan UKM dan koperasi di Indonesia.

2. Akuntansi sangat penting untuk transparansi dan akuntabilitas keuangan UKM dan koperasi di Indonesia.

3. Akuntansi sangat bermanfaat dalam konsep pertanggungjawaban UKM dan koperasi di Indonesia.

\section{DAFTAR PUSTAKA}

Anthony Robert. N, James S. Recee, Julie $\mathrm{H}$. Hertenstein, Accounting Text and Cases, $9^{\text {th }}$ ed. Chicago : Richard D Irwin, 1995

Edmonds, Thomas P, et Al., Fundamental Financial Accounting Concepts, $2^{\text {nd }}$ ed. Boston : Irwin : Mc Graw Hill, 1998

Horngren \& Foster, Akuntansi Beban, Penerbit Salemba Empat, Jakarta, 1995

Horngren \& Harrison \& Harrison \& Robinson, Akuntansi di Indonesia, Penerbit Salemba Empat, Jakarta, 1996

IAI, Standar Akuntansi Keuangan, Jakarta : Penerbit Salemba Empat, 2007

Meighs \& Meighs, Accounting : The Basis for Business Decisions, $2^{\text {nd }}$ ed. Ohio, South Western College Publishing, 1996

Matz \& Usry \& Hammer, Akuntansi Beban, Penerbit Erlangga, Jakarta, 1993 
Performance - Vol.22 No.2 September 2016

Rudianto, 2010. Akuntansi Koperasi edisi ke 2

Siegel, Joel G \& Shim, Jae K, Kamus Istilah Akuntansi, Elex Media Komputido, 1995

Sony Warsono, Endra Murti. M, Arsyadi Ridho, Arif Darmawan. 2010, Akuntansi UMKM
William Lee, 2011. Manajemen Keuangan Usaha Kecil

Situs :

http://consumerbehaviour.lecture.ub.ac.id/ 2011/12/artikel-tentang$\underline{\mathrm{ukm} /}$ 